\title{
Injecting Poultry Litter into Orchardgrass Hay
}

\author{
Stephanie B. Kuleszaa ${ }^{a}$ Rory O. Maguire ${ }^{a}$, Wade E. Thomason ${ }^{a}$, and Dan H. Pote \\ aDepartment Crop and Soil Environmental Sciences, Virginia Tech, Blacksburg, Virginia, USA.; 'bSDA-ARS, Dale \\ Bumpers Small Farms Research Center, Booneville, Arkansas, USA
}

\begin{abstract}
Traditional surface application of poultry litter leaves nutrients vulnerable to loss through volatilization and runoff. However, injection can increase capture of these nutrients in agricultural fields. Therefore, a field experiment was conducted to determine the effects of poultry litter injection on orchardgrass (Dactylis glomerata L.) hay yield and quality. Poultry litter was injected or surface applied using the Subsurfer poultry litter injector at the recommended agronomic rate (high) and half that rate (low) in 2012 and 2013 in an established field of orchardgrass. Soil was sampled to $15 \mathrm{~cm}$ and analyzed for soil nitrate. No significant differences in soil nitrate were detected between treatments. Although not always statistically significant, first cutting orchardgrass yields tended to be greater with surface litter application. Injected treatments had greater protein concentrations than their respective surface treatment, showing greater nitrogen uptake, when protein was weighted by yield. Protein was the same for high surface and low injected treatments showing that similar nitrogen $(\mathrm{N})$ uptake was achieved.
\end{abstract}

\section{ARTICLE HISTORY}

Received 20 January 2015

Accepted 27 December 2015

\section{KEYWORDS}

Fertility; manure injection; nutrient management; poultry litter

\section{Introduction}

Manures are typically surface applied to agricultural fields and sometimes incorporated through tillage to provide nutrients that are valuable for crop production. While tillage is fast and cost efficient, tillage is not compatible with no-till or forage systems and can destroy benefits provided by no-till farming, which means surface application of manure is common in these settings (Maguire, Kleinman, and Beegle 2011a). However, traditional surface application leaves manure on the soil surface vulnerable to loss through runoff and volatilization of ammonia-nitrogen (N) $\left(\mathrm{NH}_{3}-\mathrm{N}\right)$. Recent technical advances mean that manure can be incorporated into the soil without tillage, using manure injection techniques (Maguire et al. 2011b).

Manure injection systems create minimal soil disturbance while partially burying surface residues, which could make them compatible with no-till and forage systems (Dell, Meisinger, and Beegle 2011). However, commercially available equipment for injecting manure only accommodates liquid manure, and much of the research available on manure injection excludes dry poultry litter. Poultry litter injection using the Subsurfer places poultry litter into the soil without tillage, reducing soil disturbance (Pote et al. 2011). Injection of manure reduces $\mathrm{N}$ and phosphorus (P) losses from agricultural fields in runoff and $\mathrm{NH}_{3}-\mathrm{N}$ volatilization relative to surface application (Maguire 2008; Maguire, Kleinman, and Beegle 2011a; Maguire et al. 2011b; Moore et al. 2011; Pote et al. 2003, 2011, 2009; Watts, Way, and Torbert 2011).

Watts, Way, and Torbert (2011) reported that losses of $\mathrm{N}$ and $\mathrm{P}$ in runoff were reduced to those of a no poultry litter control when poultry litter was injected. Manure injection not only reduces nutrient losses but also increases the $\mathrm{N}$ use efficiency of manures (Maguire, 2008). Ammonia- $\mathrm{N}$ 
volatilization was reduced to zero when poultry litter was injected (Moore et al. 2011). Reductions in $\mathrm{NH}_{3}-\mathrm{N}$ volatilization are due to increased contact of manure with soil solids and decreased contact of manure with the atmosphere, which increases immobilization of ammonium-N $\left(\mathrm{NH}_{4}{ }^{+}-\mathrm{N}\right)$ (Dell, Meisinger, and Beegle 2011). Although there is only limited research available, this decrease in ammonia volatilization by poultry litter injection should increase the amount of $\mathrm{N}$ in the soil available for crop uptake. For example, a laboratory study by Kulesza et al. (2014) simulated poultry litter injection and reported increased soil total inorganic $\mathrm{N}$ when compared with surface application. Increased $\mathrm{N}$ availability has the potential to increase yields because $\mathrm{N}$ is the most common limiting nutrient in agricultural production and can increase the quality of crops produced (Eckert 2007). A major concern for forage production is maintaining forage quality that supports the desired level of weight gain or milk production, which is partially dependent on N. Crude protein, acid detergent fiber (ADF), neutral detergent fiber (NDF), and total digestible nutrient (TDN) concentrations can be used as indicators of feedstock quality (Ball et al. 2001). Although not always statistically significant, poultry litter injection showed a tendency to increase yields and crude protein of bermudagrass hay (Pote et al. 2009). When poultry litter was injected rather than surface applied, corn yields increased by $36 \%$ and 20\% in 2008 and 2009, respectively (Pote et al. 2011). With increased nutrient capture, crop yield, and crop quality, poultry litter injection could be a valuable alternative to traditional surface application, providing agricultural and environmental benefits.

While much research has been done on liquid manure injection, more research is needed to evaluate injection of dry poultry litter. Information is needed to determine the effects of poultry litter injection on yield and quality of crops when compared with traditional surface application. Therefore, the objective of this study was to determine the effect of poultry litter injection on soil inorganic $\mathrm{N}$, yield, and quality of orchardgrass hay when compared with traditional surface application.

\section{Materials and methods}

\section{Site and soil description and poultry litter analysis}

This study was conducted on a private farm near Mauzy, VA, in the Shenandoah Valley. Prior to this study, the orchardgrass plots had been under established orchardgrass hay production. Field soils were fairly uniform ranging from the Frederick (fine, mixed, semi-active, mesic typic paleudult) to the Lodi (fine, mixed, subactive, mesic typic hapludult) soil series. Initial soil samples ( $n=5$ cores) were combined from 0 to $15 \mathrm{~cm}$ depth, dried, and sieved $(2 \mathrm{~mm})$ prior to initiation of these field studies in 2012. Organic matter concentration was determined on a weight basis using loss on ignition adapted from AOAC method 2.7.08 (Cunniff 1996). Soil organic matter concentration in the orchardgrass field was $3.1 \mathrm{~g} \mathrm{~kg}^{-1}$ prior to starting the experiment in 2012. Water $\mathrm{pH}$ was determined using a 1:1 soil to distilled water volume to volume ratio stirred for $10 \mathrm{~min}$ to allow equilibration. Water $\mathrm{pH}$ was then measured using an automated $\mathrm{pH}$ analyzer (Kalra 1995). The $\mathrm{pH}$ was 6.61 and within agronomic range for crop production (Maguire and Heckendorn 2011). Mehlich I P was determined using a method adapted from Mehlich (1953) as described by Maguire and Heckendorn (2011) by extraction of a 1:1 solution to soil ratio, filtered (Whatman \#2), and analyzed on an ICP-OES (Mehlich 1953). Mehlich-I $\mathrm{P}$ was in the "very high" category at $100 \mathrm{mg} \mathrm{kg}^{-1}$ in the orchardgrass field.

Average values of organic $\mathrm{N}, \mathrm{NH}_{4}{ }^{+}-\mathrm{N}$, total $\mathrm{P}$, and moisture in poultry litters tested in Virginia are $26.7,5.7,11.4 \mathrm{~g} \mathrm{~kg}^{-1}$, and $27.8 \%$, respectively (VADCR 2005). Fresh poultry litter samples were collected at the time of application each year. Organic $\mathrm{N}$ was determined by Kjeldahl (1883) digestion using the concentrated sulfuric acid method as described by Peters (2003). In 2012, poultry litter had $28.7 \mathrm{~g} \mathrm{~kg}^{-1}$ organic $\mathrm{N}$ and $33.6 \mathrm{~g} \mathrm{~kg}^{-1}$ in 2013 . Also, litter from both years had higher organic $\mathrm{N}$ concentrations than the average organic $\mathrm{N}$ of poultry litters tested in Virginia (VADCR 2005). To determine $\mathrm{NH}_{4}{ }^{+}-\mathrm{N}$, poultry litter was extracted with potassium chloride $(\mathrm{KCl})$ at a 1:10 litter to $\mathrm{KCl}$ ratio, and ammonium-N was determined using 
the boric acid indicator method adapted from AOAC method 973.49 and EPA method 350.2 (Peters 2003). Ammonium-N was $8.1 \mathrm{~g} \mathrm{~kg}^{-1}$ in 2012 and $7.4 \mathrm{~g} \mathrm{~kg}^{-1}$ in 2013, and both litters had higher $\mathrm{NH}_{4}{ }^{+}-\mathrm{N}$ than the average of litters tested in Virginia (VADCR 2005). Total P was determined by digestion with concentrated nitric acid using the wet ashing method as described by Peters (2003) adapted from AOAC 985.01 and analyzed on ICP-OES. The concentration of P in poultry litter was $8.0 \mathrm{~g} \mathrm{~kg}^{-1}$ in 2012 and $12.3 \mathrm{~g} \mathrm{~kg}^{-1}$ in 2013 . A representative $10-20 \mathrm{~g}$ subsample of litter was dried at $110{ }^{\circ} \mathrm{C}$ until a constant weight was achieved to determine moisture (Peters 2003). Poultry litter from both years had lower moisture than averages in Virginia (VADCR 2005).

\section{Orchardgrass hay trials}

Orchardgrass hay plots $2.5 \mathrm{~m} \times 6.1 \mathrm{~m}$ were laid out in a split-plot design with application rate being the main plot and application method the subplot. Four treatments were used with 4 replications: high rate injection (HI), high rate surface (HS), low rate injection (LI), and low rate surface (LS) applications totaling 16 plots. All plots were treated with poultry litter collected on site from houses for broiler (Gallus gallus domesticus) production. Poultry litter was applied using the Subsurfer poultry litter injector (Pote et al. 2009) to ensure consistent application rate, with the coulters being lifted above ground for the surface application. Poultry litter was injected to a depth of $5 \mathrm{~cm}$ as described by Pote et al. (2009). High rate application was determined using a nitrogen-based application rate, poultry litter analysis, soil productivity grouping, and state nutrient management regulations (VADCR 2005). Plant-available N (PAN) from the poultry litter application was calculated using $60 \%$ organic $\mathrm{N}$ mineralization in a growing season for all treatments and $95 \% \mathrm{NH}_{4}{ }^{+}-\mathrm{N}$ availability for the injected treatment (VADCR 2005). There is no book value for $\mathrm{NH}_{4}{ }^{+}-\mathrm{N}$ availability when injecting poultry litter, therefore the values for liquid manure injection (95\%) were used (VADCR 2005). In 2012, the high rate (10.80 magnesium $(\mathrm{Mg}) \mathrm{ha}^{-1}$ ) application was determined assuming 95\% $\mathrm{NH}_{4}{ }^{+}-\mathrm{N}$ capture and $60 \%$ organic $\mathrm{N}$ mineralization for the injected treatment (Table 1). As $\mathrm{NH}_{4}{ }^{+}-\mathrm{N}$ capture for surface application is only $50 \%$, the calculated PAN for HS was slightly below the recommended PAN (VADCR 2005). Low rate application was half of the high rate application at $5.40 \mathrm{Mg} \mathrm{ha}^{-1}$ because an $\mathrm{N}$ response from injection would be more easily detected with a suboptimal $\mathrm{N}$ rate. Poultry litter was injected to a depth of $5 \mathrm{~cm}$ as described by Pote et al. (2009) on 28 March 2012 and 23 April 2013 into a field of orchardgrass established using the Shilo cultivar, and treatments were applied to the same plots in both years. According to VADCR (2005), poultry litter can be applied at $90 \mathrm{~kg} \mathrm{~N} \mathrm{ha}^{-1}$ per expected cutting not to exceed $280 \mathrm{~kg} \mathrm{~N} \mathrm{ha}{ }^{-1}$ annually. In 2012, poultry litter was applied at $269 \mathrm{~kg} \mathrm{~N} \mathrm{ha}^{-1}$ for the HI treatment in one spring application with anticipation of three hay cuttings. As only two cuttings were achieved in 2012, highrate and low-rate poultry litter treatments were applied at $179 \mathrm{~kg} \mathrm{~N} \mathrm{ha}^{-1}\left(7.20 \mathrm{Mg} \mathrm{ha}{ }^{-1}\right)$ and $90 \mathrm{~kg} \mathrm{~N} \mathrm{ha}^{-1}$ (3.60 $\mathrm{Mg} \mathrm{ha}^{-1}$ ), respectively, with anticipation of two hay cuttings in 2013 . However, three cuttings were achieved in 2013 due to good growing conditions. Reference plots $(3.0 \mathrm{~m} \times$ $6.1 \mathrm{~m}$ ) were laid out in a randomized complete block design with three replicates of four urea rates. Reference plots were fertilized using split applications of urea. For reference plots, five urea rates were used with three replications: $0,22,45,67$, and $90 \mathrm{~kg} \mathrm{~N}$ ha $^{-1}$ for each cutting, totaling 15 plots.

Table 1. Poultry litter and plant-available N (PAN) from litter and starter fertilizer applied to the corn and orchardgrass plots.

\begin{tabular}{llccccc}
\hline & & \multicolumn{2}{c}{2012} & & \multicolumn{2}{c}{2013} \\
\cline { 3 - 4 } \cline { 5 - 6 } Rate & Application method & Litter rate $\left(\mathrm{Mg} \mathrm{ha}^{-1}\right)$ & PAN $\left(\mathrm{kg} \mathrm{ha}^{-1}\right)$ & & Litter rate $\left(\mathrm{Mg} \mathrm{ha}^{-1}\right)$ & PAN $\left(\mathrm{kg} \mathrm{ha}^{-1}\right)$ \\
\hline High & Injected & 10.8 & 269 & 7.3 & 179 \\
& Surface & 10.8 & 230 & 7.3 & 153 \\
\multirow{2}{*}{ Low } & Injected & 5.4 & 135 & 3.7 & 90 \\
& Surface & 5.4 & 115 & 3.7 & 77 \\
\hline
\end{tabular}


These $\mathrm{N}$ rates were applied once in spring and after each cutting except the last one in fall. Potash was applied each spring to reference plots at a rate of $151 \mathrm{~kg} \mathrm{~K} \mathrm{ha}^{-1}$ based on soil test recommendations (VADCR 2005). Forage samples were collected by harvesting $0.76 \mathrm{~m}$ width at $7.5 \mathrm{~cm}$ cutting height from the middle of the plot after plot edges had been mowed using a walk behind harvester. Forage yields were determined by dividing the weight of sample by the area of cutting. At time of cutting, a subsample was collected, weighed, dried to a constant weight at $57^{\circ} \mathrm{C}$, and ground using a Wiley mill fitted with a $1 \mathrm{~mm}$ screen. Samples were then analyzed using a FOSS XDS NIR rapid content analyzer (FOSS NIR Systems, Laurel, MD, USA) to determine protein, ADF, NDF, and TDN. Using Eq. (1), TDN was calculated using the western formula (Adams 1980):

$$
\mathrm{TDN} \%=80.4-(0.481 \times \mathrm{ADF} \%)
$$

Protein was weighted by yield to determine the protein content of the cumulative forage collected annually. Weighted protein (WP) was determined using the protein and yield of each cutting (Eq. (2)):

$$
\mathrm{WP}=\frac{\left(\text { Cut } 1 \text { protein }\left(\mathrm{Mg} \mathrm{Mg}^{-1}\right) \times \text { yield }\left(\mathrm{Mgha}^{-1}\right)\right)+\left(\text { Cut } 2 \text { protein }\left(\mathrm{Mg} \mathrm{Mg}^{-1}\right) \times \text { yield }\left(\mathrm{Mg} \mathrm{ha}^{-1}\right)\right)+\ldots}{\text { Total yield }}
$$

Milk equivalence was then determined using the University of Wisconsin MILK2006 equation for alfalfa (Undersander et al. 2006). Fertilizer $\mathrm{N}$ equivalence was determined by inputting each treatment yield into the respective inorganic $\mathrm{N}$ yield response curve equation of each cutting or cumulative yield found in Figures 1a-1c.

Soil samples were collected from 0 to $15 \mathrm{~cm}$ to determine soil inorganic $\mathrm{N}$ approximately 3 months after litter application in 2012 and 2 months after application in 2013. Soil samples within the litter treatment plots and reference plots were collected, dried at $57{ }^{\circ} \mathrm{C}$, ground, sieved $(2 \mathrm{~mm})$, and analyzed for $\mathrm{NO}_{3}{ }^{-} \mathrm{N}$ and $\mathrm{NH}_{4}{ }^{+}-\mathrm{N}$. For $\mathrm{NO}_{3}{ }^{-} \mathrm{N}$ and $\mathrm{NH}_{3}-\mathrm{N}$ determination, $3 \mathrm{~g}$ subsample was extracted with $30 \mathrm{~mL}$ of $2 \mathrm{M} \mathrm{KCl}$ by shaking for $1 \mathrm{~h}$ (Bremner and Keeney 1966). Samples were filtered through a $0.45 \mu \mathrm{m}$ filter connected to a vacuum pump and refrigerated until analysis. Nitrate- $\mathrm{N}$ and $\mathrm{NH}_{3}-\mathrm{N}$ were determined colorimetrically using QuickChem 12-107-04-1-B (Knepel 2001) by means of Cd reduction and QuickChem sodium salicylate method 12-107-06-02-A (Hofer 2001) on a Lachat flow injected colorimeter.

\section{Statistical analysis}

Data were analyzed using analysis of variance, and mean separation was achieved using the Student's $t$-test in JMP Pro 10 (SAS Institute, Cary, NC, USA). Statements of significance were declared at $\alpha<0.1$ for main treatment factors. Analysis of variance was used to determine significant linear or quadratic regression fits when conducting a simple linear regression. Error bars in all figures represent the standard deviation of the mean.

\section{Results and discussion}

\section{Orchardgrass hay trials}

\section{Soil nitrate}

In 2012, all treatments were similar with 6.44, 3.67, 3.08, and $3.38 \mathrm{mg} \mathrm{kg}^{-1} \mathrm{NO}_{3}{ }^{-} \mathrm{N}$ for HI, HS, LI, and LS treatments, respectively. In 2013, it is suggested that soil $\mathrm{NO}_{3}{ }^{-} \mathrm{N}$ was much greater than in 2012 due to more rainfall, warmer temperatures, and less time for plant uptake of $\mathrm{N}$ between application and soil sampling. Between application of manure and sampling for soil $\mathrm{NO}_{3}{ }^{-} \mathrm{N}$, the average temperature for 2012 was $23.2{ }^{\circ} \mathrm{C}$ with $17.5 \mathrm{~cm}$ of precipitation. In 2013, the average temperature was $24.3{ }^{\circ} \mathrm{C}$ with $20.0 \mathrm{~cm}$ precipitation between application of manure and sampling 

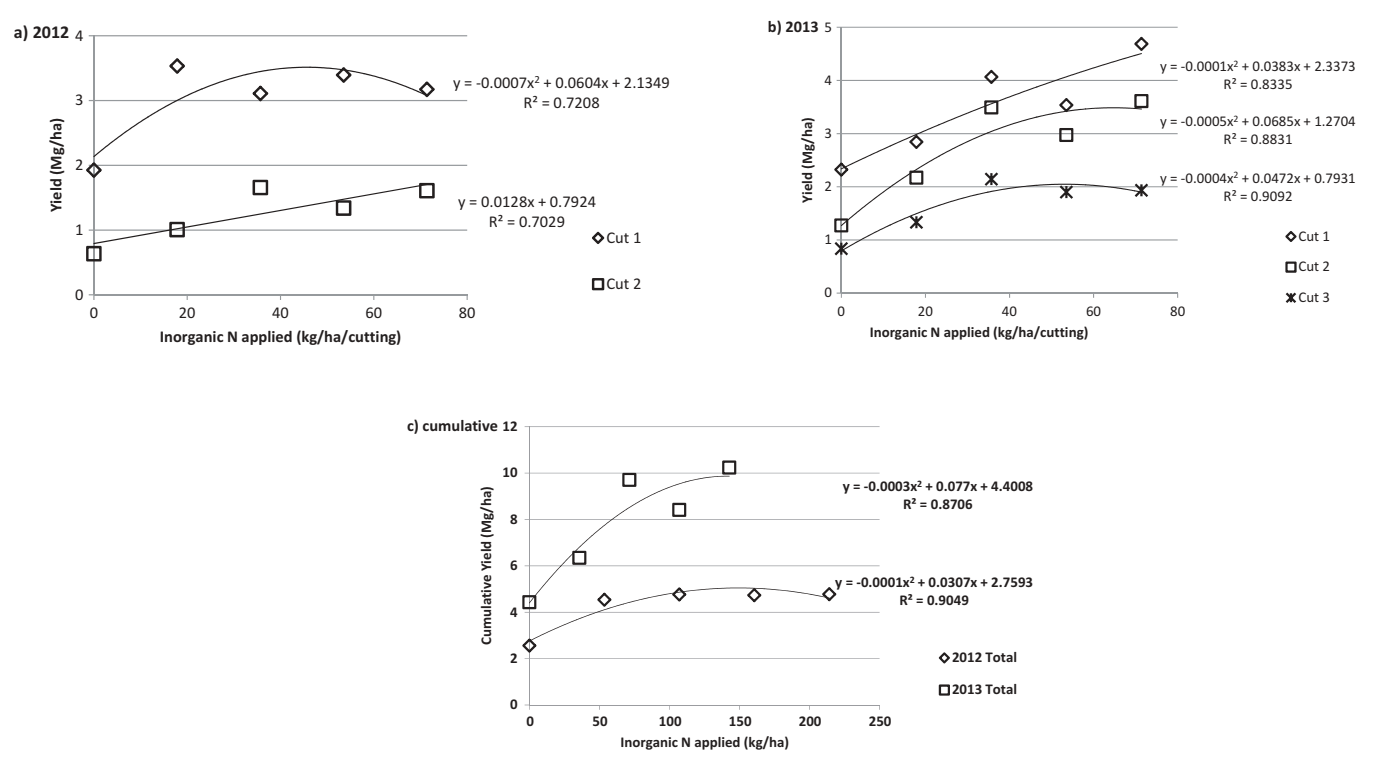

Figure 1. Yield response to varying application rates of urea fertilizer in orchardgrass hay for a) two cuts in 2012, b) three cuts in 2013, and c) cumulative yields for 2012 and 2013.
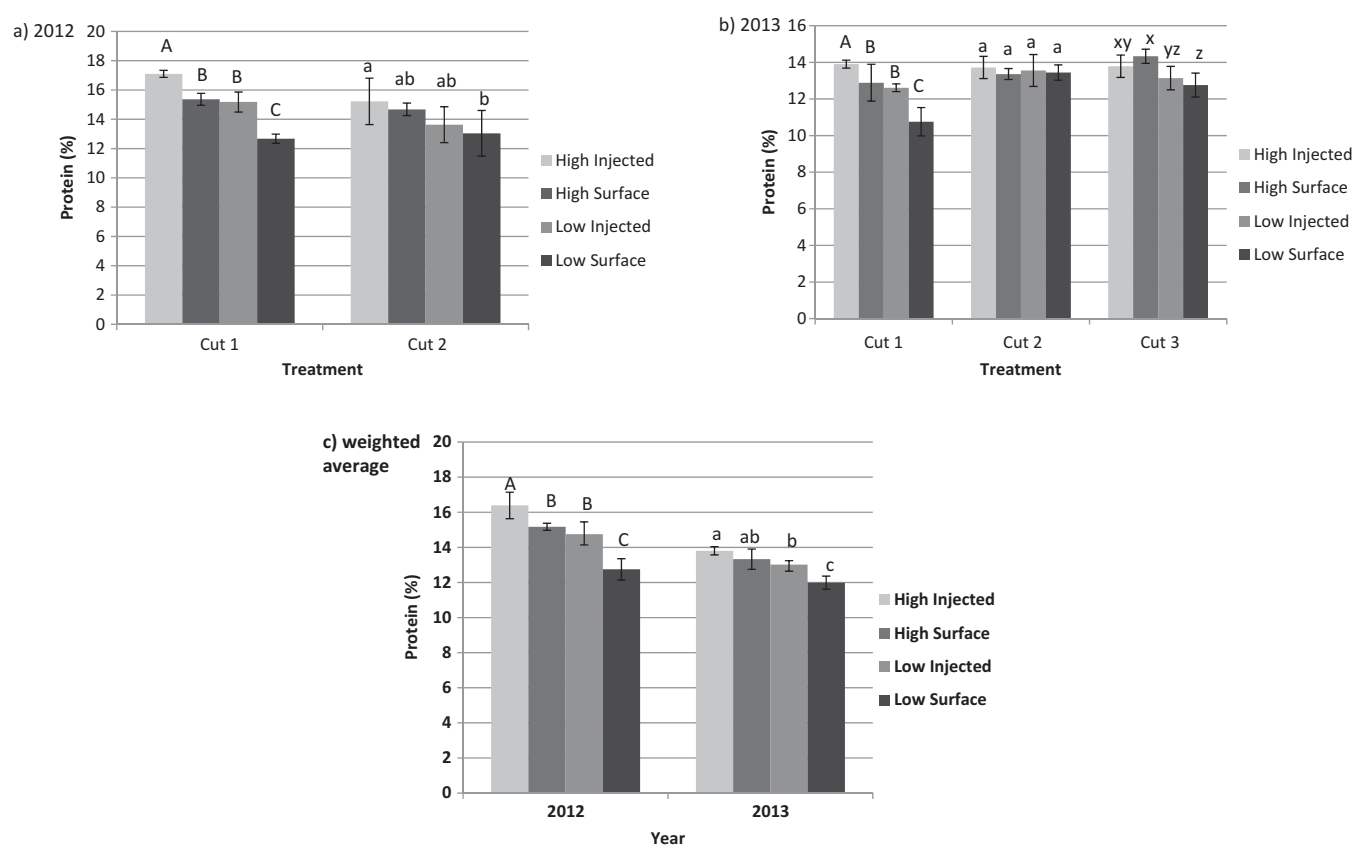

Figure 2. Percent protein in orchardgrass hay for a) two cuts in 2012 , b) three cuts in 2013 , and c) weighted average of all cuts in 2012 and 2013 for high injected, high surface, low injected, and low surface treatments.

for soil $\mathrm{NO}_{3}{ }^{-} \mathrm{N}$. There were no significant differences in soil $\mathrm{NO}_{3}{ }^{-} \mathrm{N}$ in 2013 . However, the average soil $\mathrm{NO}_{3}{ }^{-} \mathrm{N}$ was numerically greatest for the $\mathrm{HI}$ treatment with $34.13 \mathrm{mg} \mathrm{kg}{ }^{-1}$, but this was not significantly greater than the HS treatment which had $27.71 \mathrm{mg} \mathrm{kg}^{-1}$. There were no significant differences between low injected and low surface treatments for soil $\mathrm{NO}_{3}{ }^{-} \mathrm{N}$ in either 2012 or 2013. 
Table 2. Orchardgrass yield for 2012 and 2013 after poultry litter was surface applied or injected at high and low rates.

\begin{tabular}{|c|c|c|c|c|c|c|c|c|c|c|c|c|c|c|}
\hline \multirow[b]{3}{*}{ Treatment } & \multicolumn{6}{|c|}{2012} & \multicolumn{8}{|c|}{2013} \\
\hline & \multicolumn{2}{|c|}{ Cut 1} & \multicolumn{2}{|c|}{ Cut 2} & \multicolumn{2}{|c|}{ Cumulative } & \multicolumn{2}{|c|}{ Cut 1} & \multicolumn{2}{|c|}{ Cut 2} & \multicolumn{2}{|c|}{ Cut 3} & \multicolumn{2}{|c|}{ Cumulative } \\
\hline & \multicolumn{6}{|c|}{$\mathrm{Mg} \mathrm{ha}^{-1}$} & \multicolumn{8}{|c|}{$\mathrm{Mg} \mathrm{ha}^{-1}$} \\
\hline High injection & 2.5 & ns & 1.5 & ns & 4.0 & ns & 3.1 & $A^{a}$ & 2.5 & $\mathrm{~ns}$ & 1.6 & ns & 7.2 & A \\
\hline High surface & 2.7 & ns & 1.1 & ns & 3.8 & ns & 3.0 & A & 2.2 & ns & 1.3 & ns & 6.6 & $A B$ \\
\hline Low injection & 2.3 & $\mathrm{~ns}$ & 0.9 & ns & 3.2 & ns & 2.5 & B & 1.8 & ns & 1.3 & $\mathrm{~ns}$ & 5.6 & B \\
\hline Low surface & 2.7 & ns & 1.0 & ns & 3.7 & ns & 3.0 & A & 1.8 & ns & 1.2 & ns & 6.1 & B \\
\hline
\end{tabular}

${ }^{a}$ Means within the same column followed by different letters are significantly different at the 0.05 probability level.

\section{Yield}

In 2012, average yield of the first cut was similar across treatments (Table 2). Nitrogen would not have been a limiting factor for the first cut of hay, as sufficient $\mathrm{N}$ was applied at the start of the season for three cuts over the growing season. Therefore, any extra $\mathrm{N}$ availability would be expected to show up later in the growing season. For the second cut of 2012 and for the cumulative yield, there were no significant differences between injection and surface application for either high or low poultry litter rates. Due to more rain and better orchardgrass regrowth, an extra hay cutting was harvested in 2013 than in 2012. In 2013, there was a similar trend for hay growth between the treatments. There was no significant difference between HI and HS treatments throughout the growing season. However, yield of LS was greater than LI in the first cut of 2013 with 3.0 and 2.5 $\mathrm{Mg} \mathrm{ha}^{-1}$, respectively, indicating surface application may provide more $\mathrm{N}$ initially due to rapid aerobic microbial activity at the soil surface. However, looking at the cumulative yields from all three cuts in 2013, there was no effect of injection on yield, with HI = HS $\geq$ LI = LS. These results were similar to those found by Warren et al. (2008) but different to those found by Pote et al. (2003, 2009). Warren et al. (2008) found that yield was the same when injecting or surface applying poultry litter into tall fescue and bermudagrass fields. This study further supports literature showing that injection has no detrimental impact on yield in warm or cool season perennial grass production due to root damage during application in the spring. Pote et al. (2003) found that cumulative forage yields were $25 \%$ higher when injection was simulated; however, these differences were not always significant. Pote et al. (2003) injected by hand and stepped on the injection slits to ensure closure which could have caused less soil disturbance and increased closure of injection slits when compared with this study, which used mechanized injection. Pote et al. (2009) found that the total yield was increased by $40 \%$ when poultry litter was injected compared with surface broadcast, but these differences were not always significant.

Yield response curves showed quadratic relationships for cut 1 yield and cumulative yield in 2012 and cut 2 yield, cut 3 yield, and cumulative yield in 2013 in response to increased inorganic fertilizer application (Figures 1a-1c). Linear relationships were found for cut 2 in 2012 and cut 1 in 2013 in response to increasing inorganic fertilizer applications. Using the first derivative of the quadratic equations, the optimum $\mathrm{N}$ application rate was $43 \mathrm{~kg} \mathrm{~N} \mathrm{ha}^{-1}$ cutting ${ }^{-1}$ for cut 1 in 2012, and 69 and $59 \mathrm{~kg} \mathrm{~N} \mathrm{ha}^{-1}$ cutting $^{-1}$ for cut 2 and cut 3, respectively, in 2013. For cumulative yields, optimum $\mathrm{N}$ application rate was 154 and $128 \mathrm{~kg} \mathrm{~N} \mathrm{ha}^{-1}$ for 2012 and 2013, respectively. Optimum N rate could not be calculated for cut 2 in 2012 or cut 1 in 2013 because the optimum $\mathrm{N}$ rate was exceeded by the application rates used in this experiment. In the first cut of 2012, the $\mathrm{N}$ equivalence was greatest in HS treatment with $12.3 \mathrm{~kg} \mathrm{~N} \mathrm{ha}^{-1}$ and lowest in the LI treatment with $2.3 \mathrm{~kg} \mathrm{~N} \mathrm{ha}^{-1}$. LS and HI treatments were intermediate with 10.6 and $6.7 \mathrm{~kg} \mathrm{~N} \mathrm{ha}^{-1}$, respectively, and similar to the HS and LI treatments (data not shown). In the second cut of 2012, the $\mathrm{N}$ equivalence was 51.9, 22.7, 17.3, and $11.5 \mathrm{~kg} \mathrm{~N} \mathrm{ha}^{-1}$ for HI, HS, LS, and LI, respectively. However, the HS treatment was not significantly different from any other treatment, and the LS treatment was similar to the LI treatment. Using cumulative yield of 2012, HI had the greatest and LI had the lowest $\mathrm{N}$ equivalence provided by 
poultry litter application. HS and LS were intermediate but were similar to HI and LI treatments. In all cuts of 2013, there were no differences in $\mathrm{N}$ equivalence between any treatments.

\section{Forage quality}

No observable trends were found between treatments for ADF, NDF, and TDN in 2012 or 2013 (data not shown). The protein concentration in the first cut of hay from 2012 was greatest in the HI treatment with $17.1 \%$ and lowest in the LS treatment with $12.7 \%$ (Figure 2a). The HS and LI treatments had similar protein concentrations and yields in cuts 1 and 2 in 2012. Therefore, $\mathrm{N}$ uptake was similar for $\mathrm{HS}$ and LI treatments, which indicates that injection increased $\mathrm{NH}_{4}{ }^{+}-\mathrm{N}$ capture which provided more $\mathrm{N}$ for crop production when using injection. Protein is directly related to $\mathrm{N}$ uptake by forages (Johnson et al. 2001; Malzer and Schoper 1984). Johnson et al. (2001) found that increasing inorganic $\mathrm{N}$ fertilization rates elevated crude protein in bermudagrass. Malzer and Schoper (1984) showed that crude protein in orchardgrass, reed canary grass (Phalaris arundinacea), and quackgrass (Elytrigia repens) increased with increasing $\mathrm{N}$ rates using inorganic fertilizer. Increased protein in injected treatments can be related to soil $\mathrm{NO}_{3}{ }^{-} \mathrm{N}$ values discussed earlier, where soil $\mathrm{NO}_{3}{ }^{-} \mathrm{N}$ concentrations were similar for HS and LI treatments, therefore the amount of $\mathrm{N}$ available for plant uptake and protein synthesis was the same. Also, protein concentrations for both injected treatments were greater than their corresponding surface treatments in cut 1 of 2012 which correlates to higher $\mathrm{N}$ use efficiency of poultry litter $\mathrm{N}$ when using injection. In the second cut of 2012, all treatment combinations had similar protein concentrations. In the first cut of 2013, HI had the greatest protein concentration with $13.9 \%$ and the LS treatment had the lowest with $10.8 \%$ (Figure 2b). HS and LI treatments were not significantly different in the first cut of 2013 and intermediate to the other two treatments with $12.9 \%$ and $12.6 \%$, respectively. In the second and third cut of 2013, there were no significant treatment effects on protein concentration. When protein concentration was weighted by yield in 2012, it followed the order HI > HS = LI > LS. Therefore, for both the high and low rates, injection increased nitrogen use efficiency of the manure applied in 2012 (Figure 2c). The trend was similar in 2013, although HI was not significantly greater than HS. On average, protein was $1.2 \%$ and $2.0 \%$ greater for high and low rate injection treatments, respectively, relative to the equivalent surface application rate in 2012 , and protein was $0.5 \%$ and $1.0 \%$ greater than the respective surface application rate for high and low rate, respectively, in 2013. Similar results were found by Mooleki et al. (2002) and Pote et al. (2009). Mooleki et al. (2002) found that $\mathrm{N}$ concentration was higher in wheat, barley, and canola when dairy manure was injected, however this was not always significant. Pote et al. (2009) found that mean protein and digestibility of bermudagrass was higher for injected poultry litter when compared with surface broadcast, although not always significant. Pote et al. (2009) found a range of $13-21 \%$ protein concentration for forages when poultry litter was surface applied or injected. Protein averages reported by Pote et al. (2009) are greater than averages found in this study. However, Pote et al. (2009) injected into bermudagrass, a warm-season grass, pasture, while this study involved orchardgrass, a cool-season grass, pasture. Therefore, this study shows that injection can increase protein content when compared with surface application in a cool-season grass. Protein and TDN are common indicators of nutritive value of feedstocks (Adesogan et al. 2009). Greater protein and TDN would correlate to higher-quality feed. Using the MILK2006 equation, calculated milk equivalence showed a general trend of HI > HS > LI > LS (data not shown). However, there were no significant differences between treatments.

\section{Conclusions}

Poultry litter injection using the Subsurfer had a tendency to increase average soil $\mathrm{NO}_{3}{ }^{-} \mathrm{N}$ compared with surface application, but cumulative orchardgrass yields showed no differences between treatments, which could indicate over-application of poultry litter. However, there was frequently increased protein when injecting poultry litter versus surface applying at the same rate. 
With previously established environmental benefits and increased quality of orchardgrass hay, injection could be a valuable alternative to traditional surface application in agricultural production systems.

\section{References}

Adams, S. M. 1980. Penn State forage testing service revised regression equations. Dairy Science. Extention Memo DSE = 90-56, Pennsylvania State Univ., University Park, PA.

Adesogan, A. T., L. E. Sollenberger, Y. C. Newman, and J. E. Moore. 2009. Factors affecting forage quality. EDIS Publication SS-AGR-93. Department of agronomy, institute of food and agricultural sciences, University of Florida, FL. http://edis.ifas.ufl.edu/pdffiles/AG/AG16100.pdf (accessed 12 February 2014).

Ball, D. M., M. Collins, G. D. Lacefield, N. P. Maitin, D. A. Mertens, K. E. Olson, D. H. Putnam, D. J. Undersander, and M. W. Wolf. 2001. Understanding forage quality. Park Ridge, IL: Publ. 1-01. American Farm Bureau Federation Publication.

Bremner, J. M., and D. R. Keeney. 1966. Determination and isotope-ratio analysis of different forms of nitrogen in soils: 3. Exchangeable ammonium, nitrate, and nitrite by extraction-distillation methods. Soil Science Society of America Journal 30:577-82. doi:10.2136/sssaj1966.03615995003000050015x.

Cunniff, P. 1996. Official methods of analysis of AOAC International, 16th ed. Gaithersburg, MD: AOAC International.

Dell, C. J., J. J. Meisinger, and D. B. Beegle. 2011. Subsurface application of manures slurries for conservation tillage and pasture soils and their impact on the nitrogen balance. Journal of Environment Quality 40:352-61. doi:10.2134/ jeq2010.0069.

Eckert, D. 2007. Soil and managing soil, soil water, and fertility. In Hartmann's plant science: Growth, development, and utilization of cultivated plants, 4th ed., 53-94. Upper Saddle River, NJ.: Prentice-Hall.

Hofer, S. 2001. Determination of Ammonia (Salicylate) in $2 \mathrm{M} \mathrm{KCl}$ soil extracts by flow injection analysis. Quick Chem Method 12-107-06-2-A. Revised by K. Bogren. (2003). Lachat Instruments, Loveland, CO.

Johnson, R. C., B. A. Reiling, P. Mislevy, and M. B. Hall. 2001. Effects of nitrogen fertilization and harvest date on yield, digestibility, fiber, and protein fractions of tropical grasses. Journal of Animal Science 79:2439-48.

Kalra, Y. P. 1995. Determination of $\mathrm{pH}$ of soils by different methods: Collaborative study. Journal of AOAC International 78:310-21.

Kjeldahl, J. 1883. Neue methode zur bestimmung des stickstoffs in organischen korpern. Zeitschrift FuR Analytische Chemie 22:366-82. doi:10.1007/BF01338151.

Knepel, K. 2001. Determination of nitrate in $2 \mathrm{M} \mathrm{KCl}$ soil extracts by flow injection analysis. Quick Chem Method 12-10704-1-B. Revised by K. Bogren. (2003). Lachat Instruments, Loveland, CO.

Kulesza, S. B., R. O. Maguire, W. E. Thomason, S. C. Hodges, and D. H. Pote. 2014. Effects of poultry litter injection on ammonia volatilization, nitrogen availability, and nutrient losses in runoff. Soil Science 179 (4):190-96. doi:10.1097/SS.0000000000000058.

Maguire, R. O. 2008. Manure injection. Virginia no-till factsheet series 3. Virginia Cooperative Extension, Blacksburg, VA. http://www.valleycrops.cses.vt.edu/2009VANTAGEAssets/FactSheets/FACTSHEET_3_manure.pdf (accessed 25 January 2013).

Maguire, R. O., and S. E. Heckendorn. 2011. Laboratory Procedures: Virginia Tech soil testing laboratory. http://www. soiltest.vt.edu/PDF/lab-procedures.pdf (accessed 26 March 2013).

Maguire, R. O., P. J. A. Kleinman, and D. B. Beegle. 2011a. Novel manure management technologies in no-till and forage systems: Introduction to the special series. Journal of Environmental Quality 40:287-91. doi:10.2134/ jeq2010.0396.

Maguire, R. O., P. J. A. Kleinman, C. J. Dell, D. B. Beegle, R. C. Brandt, J. M. McGrath, and Q. M. Ketterings. 2011 b. Manure application technology in reduced tillage and forage systems: A review. Journal of Environmental Quality 40:292-301. doi:10.2134/jeq2009.0228.

Malzer, G. L., and R. P. Schoper. 1984. Influence of time and rate of N application on yield and crude protein of three cool season grasses grown on organic soils. Canadian Journal of Plant Science 64:319-28. doi:10.4141/cjps84-046.

Mehlich, A. 1953. Determination of P, Ca, Mg, K, Na, and NH4. Soil Testing Div. Publ. 1-53. Raleigh, NC: North Carolina Department of Agriculture.

Mooleki, S. P., J. J. Schoenau, B. Hultgreen, G. Wen, and J. L. Charles. 2002. Effect of rate, frequency and method of liquid swine manure application on soil nitrogen availability, crop performance and $\mathrm{N}$ use efficiency in east central Saskatchewan. Canadian Journal of Soil Science 82:457-67. doi:10.4141/S01-057.

Moore, P. A., D. Miles, R. Burns, D. Pote, K. Berg, and I. H. Choi. 2011. Ammonia emission factors from broiler litter in barns, in storage, and after land application. Journal of Environment Quality 40:1395-404. doi:10.2134/ jeq2009.0383.

Peters, J. B. 2003. Recommended methods of manure analysis. http://learningstore.uwex.edu/assets/pdfs/A3769.pdf (accessed 26 March 2013). 
Pote, D. H., W. L. Kingery, G. E. Aiken, F. X. Han, P. A. Moore, and K. Buddington. 2003. Water-quality effects of incorporating poultry litter into perennial grassland soils. Journal of Environment Quality 32:2392-98. doi:10.2134/ jeq2003.2392.

Pote, D. H., T. R. Way, P. J. A. Kleinman, P. A. Moore Jr., J. J. Meisinger, K. R. Sistani, L. S. Saporito, A. L. Allen, and G. W. Feyereisen. 2011. Subsurface application of poultry litter in pasture and no-till soils. Journal of Environment Quality 40:402-11. doi:10.2134/jeq2010.0352.

Pote, D. H., T. R. Way, K. R. Sistani, and P. A. Moore Jr. 2009. Water-quality effects of a mechanized subsurfacebanding technique for applying poultry litter to perennial grassland. Journal of Environmental Management 90:3534-39. doi:10.1016/j.jenvman.2009.06.006.

Undersander, D., D. K. Combs, R. D. Shaver, and P. C. Hoffman. 2006. MILK2006 for alfalfa and grass. MS Excel spreadsheet www.uwex.edu/ces/dairynutrition/documents/milk2006alfalfa-grassprotected.xls (accessed 11 February 2014).

VADCR. 2005. Virginia nutrient management standards and criteria. Virginia Department of Conservation and Recreation, Richmond, VA. http://www.dcr.virginia.gov/documents/StandardsandCriteria.pdf (accessed 25 January 2013).

Warren, J. G., K. R. Sistani, T. R. Way, D. A. Mays, and D. H. Pote. 2008. A new method of poultry litter application to perennial pasture: Subsurface banding. Soil Science Society of America Journal 72:1831-37. doi:10.2136/ sssaj2007.0423.

Watts, D. B., T. R. Way, and H. A. Torbert. 2011. Subsurface application of poultry litter and its influence on nutrient losses in runoff water from permanent pastures. Journal of Environment Quality 40:421-30. doi:10.2134/ jeq2010.0089. 